Rag2 $^{-1}$ Fra2 $\operatorname{tg}$ mice showed no fibrosis or Lin ${ }^{-}$gp $38^{+}$cell expansion. ECG parameters of Rag $2^{-/}$Fra2 tg mice were not changed compared to control mice, indicating that inflammation is necessary to acquire Fra2-driven fibrotic phenotype and defects in the conduction system.

Conclusion: Fra2 overexpression and inflammation foster stromal cell-to-myofibroblast differentiation, leading to cardiac fibrosis and defects of the conduction system. Targeting this process might be a therapeutic strategy for SSc patients with disorders of cardiac involvement.

Disclosure of Interests: Mara Stellato: None declared, Michal Rudnik: None declared, Florian Renoux: None declared, Przemyslaw Blyszczuk: None declared, Elena Osto: None declared, Matthias Dewenter: None declared, Petra Seebeck: None declared, Elena Pachera: None declared, Oliver Distler Grant/ research support from: Prof. Distler received research funding from Actelion, Bayer, Boehringer Ingelheim and Mitsubishi Tanabe to investigate potential treatments of scleroderma and its complications, Consultant for: Prof. Distler has/had consultancy relationship within the last 3 years with Actelion, AnaMar, Bayer, Boehringer Ingelheim, ChemomAb, espeRare foundation, Genentech/Roche, GSK, Inventiva, Italfarmaco, iQvia, Lilly, medac, Medlmmune, Mitsubishi Tanabe Pharma, Pharmacyclics, Novartis, Pfizer, Sanofi, Serodapharm and UCB in the area of potential treatments of scleroderma and its complications. In addition, he had/has consultancy relationship within the last 3 years with A. Menarini, Amgen, Abbvie, GSK, Mepha, MSD, Pfizer and UCB in the field of arthritides and related disorders, Gabriela Kania: None declared

DOI: 10.1136/annrheumdis-2019-eular.6403

\section{OP0187 RITUXIMAB AND CYCLOPHOSPHAMIDE COMPARISON FOR EFFICACY AND SAFETY IN THE PATIENTS WITH SYSTEMIC SCLEROSIS ASSOCIATED WITH INTERSTITIAL LUNG DISEASE}

Olga Koneva, Lidia P. Ananyeva, Liudmila Garzanova, Oxana Desinova, Olga Ovsyannikova, Mayya Starovoytova. V.A. Nasonova Research Institute of Rheumatology, Moscow, Russian Federation

Background: Cyclophosphamide (CyP) is considered as a drug of choice for the treatment of interstitial lung disease (ILD) in the patients with systemic sclerosis (SSc). However, according to the literature, the use of CyP leads to rather limited and transient improvement of the pulmonary fibrosis. In this context the search for novel, more efficacious agents has been continued, such as attracting much attention retuximab (RTM).

Objectives: To compare the impact of CyP and RTM on SSc clinical manifestation and activity, and the safety of these agents in the open-label prospective nonrandomized study.

Methods: 107 patients with the confirmed SSc diagnosis and ILD evidence based on HRCT findings were enrolled into the study. All patients received low-dose and moderate-dose prednisolone regimens. 36 patients (Group A) received parenteral CyP for $12 \pm 6$ months at total dose $10.6 \pm 5 \mathrm{~g}$ (the average age $47 \pm 12$ years, females $92 \%$, SSc duration $5.0 \pm 4.8$ years, diffused/localized forms 1.6/1). 71 patients (Group B) received RTM at total dose $1.43 \pm 0.66 \mathrm{~g}$ over the follow-up period $13.2 \pm 2$ months (the average age $46 \pm 13$ years, females $83 \%$, SSc duration $5.6 \pm 4.4$ years, diffused/localized forms $1.4 / 1)$; to $32(45 \%)$ of them RTM was added to immunosupressants due to inadequate efficacy of the latter. The time courses FVC(\%), modified skin count (mRss, points), activity index (EScSG, points), left ventricle ejection fraction (LVEF,\%), mean pulmonary arterial pressure (EchoCG), and cardiac rhythm and conductivity disorders (ECG) were evaluated. Results: In Groups A and B the therapy was associated with significant decrease in mRss ( $p=0.009$ and 0,001 , respectively) and EScSG $(p=0.000165$ and 0.001 , respectively). Increase in LVEF $(61.8 \pm 7.3$ и $63.6 \pm 7.3 . p=0.02)$ was observed only in RTM-treated patients.

Evaluation of FVC time course in Groups A and B revealed significant FVC increase ( $p=0.034$ and 0.000045 , respectively), with median increment about $5 \%$. In Group A FVC 10\% FVC increase was found in the third of the patients thus exceeding respective parameter in Group $B(p=0.2)$. The patient percentage with FVC decrease by $\geq 10 \%$ was similar in both groups.

During the follow-up period no change of the other studied parameters was observed.

The therapy was better tolerated in RTM-treated group: during RTM therapy adverse reactions emerged in significantly lower proportion of the patients (11/ $14 \%$ ) compared with CyP-treated group (19/53\%), $p=0,0000$.

\begin{tabular}{|c|c|c|}
\hline Parameters & Group A & Group B \\
\hline EScSG 1 & $2.8 \pm 2^{*}$ & $2.8 \pm 1.8^{*}$ \\
\hline \multicolumn{3}{|l|}{$M \pm S D$} \\
\hline EScSG 2 & $1.4 \pm 1.17^{\star}$ & $1.3 \pm 1.1^{*}$ \\
\hline \multicolumn{3}{|l|}{$M \pm S D$} \\
\hline mRss 1 & $11.2 \pm 9.8$ * & $11.3 \pm 9.6$ * \\
\hline \multicolumn{3}{|l|}{$M \pm S D$} \\
\hline mRss 2 & $7.9 \pm 6.8 .{ }^{*}$ & $8.0 \pm 6.6^{*}$ \\
\hline \multicolumn{3}{|l|}{$M \pm S D$} \\
\hline FVC 1 & $80.5 \pm 20.1^{*}$ & $77.3 \pm 20$ * \\
\hline \multicolumn{3}{|l|}{$M \pm S D$} \\
\hline FVC 2 & $85.9 \pm 20.5^{\star}$ & $82.6 \pm 21 . *$ \\
\hline \multicolumn{3}{|l|}{$M \pm S D$} \\
\hline \multirow[t]{2}{*}{$\Delta \mathrm{FVC} \%$} & 5.4 & 5.3 \\
\hline & {$[-0.6 ; 12.3]$} & {$[0.1 ; 10.2]$} \\
\hline FVC increment by $\geq 10 \%, n / \%$ & $11 / 31$ & $14 / 19.7$ \\
\hline FVC decrement by $\geq 10 \% \mathrm{n} / \%$ & $2 / 5.6$ & $4 / 5.6$ \\
\hline
\end{tabular}

Conclusion: Both agents effectively alleviated skin induration and EScSG, and significantly improved FVC. However, CyP use for a year slightly more frequently resulted in clinically significant FVC increase, probably due to low RTM cumulative dose. RTM was better tolerated compared to CyP. The study findings substantiate potential use of anti-B-cell therapy both as a first-line agent for ILD treatment in the patients with SSc, and in the event of CyP inefficacy of poor toler ability, especially in the patients with cardiopathy.

Disclosure of Interests: None declared

DOI: 10.1136/annrheumdis-2019-eular.6816

\section{OP0188 \\ PATHOGENICITY OF FUNCTIONAL AUTOANTIBODIES AGAINST AT1R IN A MOUSE MODEL OF SYSTEMIC SCLEROSIS}

Junping Yin ${ }^{1}$, Xiaoqing Wang ${ }^{1}$, Xiaoyang Yue ${ }^{1}$, Gabriela Riemekasten ${ }^{2}$, Xinhua Yu ${ }^{1}$, Frank Petersen ${ }^{1} .{ }^{1}$ Research Center Borstel, Borstel, Germany; ${ }^{2}$ University of Lübeck, Lübeck, Germany

Background: Systemic sclerosis (SSc) is an autoimmune connective tissue disease featured by autoimmunity, fibrosis and vasculopathy. Although many autoantibodies have been detected in the sera of patients with SSc, it is not clear whether they play a role in the pathogenesis of disease. It has been reported that autoantibodies against the angiotensin-II receptor type 1 (AT1R) are present in the sera of SSc patients and are associated with several clinical symptoms of the disease, suggesting that these autoantibodies may act as pathogenic drivers Recently, our group has developed a novel mouse model for SSc by immunizing mice with human AT1R (hAT1R). From this model we were able to generate functional monoclonal antibodies agonizing AT1R.

Objectives: In the current study, we aim to clarify, whether B cells and antibodies directed against AT1R are involved in the pathogenesis of experimental SSc in vivo.

Methods: To investigate the role of B cells in the hAT1R-induced mouse model of SSc, we immunized B-cell deficient mice with hAT1R. Nine weeks after the first immunization, mice were sacrificed and sera and tissues were collected for further evaluation. To investigate the pathogenicity of anti-AT1R antibodies in the disease, monoclonal autoantibodies against hAT1R were applied to the ear of $\mathrm{C} 57 \mathrm{BI} / 6$ mice by single or repetitive injection. Mice were sacrificed 24 hours or 14 days after the first injection for single and repeated application, respectively, and ear and lung tissues were collected for further evaluation.

Results: Compared to the wild type C57BI/6 mice, hAT1R-immunized B-cell deficient mice were resistant against experimental SSc with regard to autoantibody production, inflammation in the lung and skin, and skin fibrosis. Furthermore, both single and repetitive injection of monoclonal antibodies against hAT1R induced inflammation in ears of mice. Despite this local effect, repetitive injection of antiAT1R monoclonal antibodies provoked also inflammation in the lung of mice.

Conclusion: Our data demonstrate that i) B cells are indispensable for the pathogenesis of the hAT1R-induced mouse model for SSc and ii) monoclonal antibodies against hAT1R can induce inflammation in mice. Therefore, our results support a role of autoantibodies against AT1R in the pathogenesis of SSc.

REFERENCES:

[1] Yannick Allanore, et al. Nat Rev Dis Primers 2015. 